\title{
Pedagogical documentation in early childhood education: A systematic review of the literature
}

\author{
Nur Alaçam, Ondokuz Mayıs University and Middle East Technical University, Turkey, nralacam@gmail.com \\ ORCID: 0000-0003-4477-5476 \\ Refika Olgan, Middle East Technical University, Turkey, rolgan@metu.edu.tr ORCID: 0000-0003-1953-7484
}

\begin{abstract}
This study examined 24 empirical research studies conducted over the period of 2006-2019 focusing on the practice of pedagogical documentation in early childhood education. The research studies were selected by a systematic review of various databases and in-depth review of national and international journals. Categorization of selected studies and analyses were undertaken with respect to the research method, participants in the study, publication year, purposes, findings, and the location(s) in which the study was conducted. The review of the studies provided information related to current literature as well as providing recommendations for further studies and proving implications to improve the practice of pedagogical documentation. This examination revealed that pedagogical documentation has sophisticated outcomes not only for children but also classroom teachers and families.

Keywords: Assessment, alternative assessment, documentation, pedagogical documentation, early childhood education

Received: 04.02.2020

Accepted: 19.06 .2020

Published:
\end{abstract}

\section{INTRODUCTION}

Assessment is a natural and continuous process in early childhood classrooms (Kingore, 2008) as providing effective interventions for early childhood education programs (Kagan, 2003; Rous, Lobianco, Moffett, \& Lund, 2005; Downs \& Strand, 2006). It refers to the process of collecting information about children from various forms of evidence, and then organizing and interpreting that information (McAfee, Leong \& Bodrova, 2004) to make judgments about children's development and learning (Sancisi \& Edgington, 2015). In this regard, it is a valuable tool that guides teaching and students' learning (Morrison, 2013).

Since young children cannot read and write, their assessment should be different from adults; therefore, there should be a match between their assessment method and developmental level. Since the changes in development of young children is fast, it is also necessary to assess whether their development is progressing normally (Wortham, 2012). In light of these requirements, assessment can be used for various purposes, including evaluation, diagnosis, placement, program planning, and communication with families (Wortham \& Hardin, 2016; Morrison, 2013).

Both formative and summative assessment is necessary to comprehensively understand the development of a child (Chen \& Cheng, 2011). However, there was a significant dissatisfaction with traditional assessment methods, and this led to the development of alternative assessment (Klenowski, 2002), referring to the more inclusive practice of assessment (Wortham, 2012). These alternative methods aim to measure how students can put their learning into practice (Blum \& Arter, 1996) and offer a comprehensive understanding of the achievement of an individual child (Epstein et al., 2004), rather than merely providing a letter or number representing a grade (Wortham \& Hardin, 2016). In this respect, alternative assessment methods allow children to demonstrate their understanding and performance in real life settings (McAfee \& Leong, 2011; Wortham \& Hardin, 2016). Documentation is one of these methods. Documentation shows the progress and learning of a child which cannot be demonstrated by common standardized tests and checklists (Katz \& Chard, 1996). 
In the related literature, documentation is described as a strategy for recording children's progress and achievement (Wortham, 2012); furthermore, it becomes a way of listening to a child and evaluating him/her. The type of documentation should be decided on the basis of the purpose for which it is required (Worham \& Hardin, 2016), such as creating a connection with families, celebration of the practice, and illuminating the complexity of pedagogy and theory (Fleet et al, 2011). Documentation is beneficial for all the stakeholders including children, parents, and the wider community. For teachers, it provides opportunities for assessment and self-assessment as helping them to explore what children understand, and then share these with their colleagues, as well as providing different ways for communicating ideas to others (Thornton \& Brunton, 2009). In this way, what and how children learn becomes visible (Kinney \& Wharton, 2008), teachers gain knowledge regarding how children's learning develops, and as a result, this process offers the child the opportunity for reflection and self-assessment. Moreover, parents receive information concerning their children's practices and learning style, and opportunities are provided for the community to better understand children's learning process (Thornton \& Brunton, 2009).

Documentation uses different tools and methodologies, one of which is pedagogical documentation which can be considered as "pedagogical" only if someone reflects upon it. Therefore, the function of pedagogical documentation is to promote reflection among the teachers (Alasuutari et al., 2014) in addition to including multiple authors, such as the child, family, and teacher in collaboration (Fleet et al., 2011). Pedagogical documentation is one of the effective tools that help teachers to gain information about children by enabling to see the potential of each child and support them (Rinaldi, 2000). In line with this, many teachers described it as a form of documentation enabling them to give attention to both children's initiatives and curriculum goals (Löfgren, 2017).

\section{Pedagogical Documentation as a Tool for Assessment}

The roots of pedagogical documentation can be traced back to the philosophy of Reggio Emilia and it can be viewed as a tool for continuous reflection, which makes learning visible to teachers, parents, and members of the community (Edwards, Gandini \& Forman, 1998). Caldwell (1997) described pedagogical documentation as a strategy for capturing children's learning experiences systematically through observations, interactions, and work products, and then sharing these through visual representations. In this regard, the purpose of pedagogical documentation is to explore different aspects and potential of the child (Rinaldi, 2000). It includes materials to reflect upon the pedagogical content, and these materials can be in different formats including notes, photos, audio recordings, and computer graphics (Alasuutari et al., 2014). The negotiation between process and content makes pedagogical documentation different from other traditional methods (Boehm \& Weinberg, 1997). In other words, it can be a way to provide a reflective and democratic pedagogy (Dahlberg, Moss \& Pence 2007).

Overall, in the current study, the accepted definition of pedagogical documentation is that it is a formative assessment technique to adapt teaching to meet needs of students and to understand the experiences of child, teacher, and parents (Black \& Wiliam, 1998). This process requires from teachers to present data in ways that show others what children have been thinking, feeling, or valuing. (Wien et al, 2011). Here, it is important that in the documentation the teachers observe from the child's point of view (Wortham \& Hardin, 2016), and therefore pedagogical documentation is often associated with democratic expectations (Alasuutari, et al., 2014). Also, there are various benefits of such pedagogical documentation. Initially, it contributing to the quality of the early childhood education (Katz \& Chard, 1996). Techniques of documentation panels make significant contribution to education quality (Kline, 2008), such as enhancing children's learning, taking children's ideas and work seriously, and providing a basis for teachers' continuous planning and evaluation of child development (Katz \& Chard, 1996). Moreover, documentation allows children to see their own learning and meaning is constructed for pedagogical situations (Oliveira-Formosinho \& Formosinho, 2012). Therefore, pedagogical documentation is a route for teachers' professional 
development (Wien et al., 2011). Overall, these shared experiences have various benefits, including promoting staff development, creating a climate of inquiry, promoting collaboration, communicating with children and parents, creating a meaningful dialogue, advocating the child, and involving feelings (Goldhaber \& Smith, 1997). As a result, it provides respect for the child (Oliveira-Formosinho \& Formosinho, 2012).

Pedagogical documentation could also be a means to opening possibilities for children and teachers when it is constructed through the lens of curiosity rather than assessment, and collaboration was interpreted as important in creating documentation to be shared. Therefore, pedagogical documentation must begin with an attitude of curiosity rather than determining the acquisition of knowledge (Tarr, 2010). To satisfy such curiosity, the pedagogical documentation process might be a way of introducing a reflective process to gain a better understanding of what the children already know (Tarr, 2011). Although children's participation in this procedure is important and complex process, there is a limited number of empirical analysis on the use of pedagogical documentation and other alternative assessment methods in early childhood education. More empirical research is needed to present practice of pedagogical documentation especially in the classrooms having traditional structure. Therefore, the purpose of present study is to present a clear picture about the current literature on practices of pedagogical documentation. With this aim, the current study seeks to answer the following research question: "What do we know about practices of pedagogical documentation in early childhood education?"

\section{METHODS}

This research was designed as a document analysis. In this qualitative analysis method, documents are systematically analyzed to extract meaning and develop knowledge through the steps of skimming, reading and interpretation. In other words, content analysis and thematic analysis are integrated into the process (Bowen, 2009).

\section{Data Sources and Search Strategy}

First, electronic databases including Academic Search Complete, EBSCOhost, Education Source, Education Research Complete, ERIC, Google Scholar, JSTOR, PsycINFO, SAGE Journals Online, Science Online, Science Direct, Scopus, SocINDEX, Springer Link, Taylor \& Francis Online Journals, Teacher Reference Center, ULAKBIM National Databases, Web of Science, and Wiley Online Library were systematically searched by using the search terms of "documentation", "pedagogical documentation" and "pedagogical documentation in early childhood education". Then, a detailed search of the literature was conducted using different combinations of the search terms (e.g., benefits of pedagogical documentation and the implementation of pedagogical documentation in early childhood education). One search limit was applied to select empirical research studies, which was being published in peer-reviewed journal between 2006 and 2019. References of retrieved articles were also used for forward searching. During this search process, two members of the research team screened the articles for relevance.

\section{Design, Participants and Location}

Empirical articles $(\mathrm{N}=24)$ fulfilling the above-mentioned selection criteria were included in this paper. Most of the studies were published in early childhood education or teacher education journals such as: Early Child Development and Care $(n=3)$, Early Years $(n=3)$, Early Childhood Research Quarterly ( $n=3)$, International Journal of Early Years Education $(n=3)$, Contemporary Issues in Early Childhood ( $n=2)$, European Early Childhood Education Research Journal $(n=2)$, International Journal of Early Childhood ( $n=2)$, Early Childhood Education Journal $(n=1)$, Journal of Early Childhood Teacher Education ( $n=1)$, Children \& Society $(n=1)$, Elementary Education Online ( $n=1)$, Education 3-13 $(n=1)$, and Teaching and Teacher Education $(n=1)$. 
A total of 11 countries were included in these research studies. Most of these were conducted in Sweden $(n=6)$ and Finland $(n=4)$. Other ones took placed in different countries including Germany $(n=3)$, Turkey $(n=2)$, Australia $(n=2)$, England ( $n=2)$, Norway $(n=1)$, United Arab Emirates $(n=1)$, New Zealand $(n=1)$, Canada $(n=1)$ and US $(n=1)$.

Most of these research studies were also classified as qualitative $(n=20)$, and other ones were designed as quantitative $(n=1)$, experimental $(n=1)$, and multi-method $(n=2)$. In the content of most of these studies, teachers $(n=16)$ were included as participants alone or together with children or parents.

\section{Coding Procedures}

Two researchers of the current study reviewed the selected articles and created a summary table for the empirical research studies. Table 1 summarizes the key information of these articles and it was useful in synthesizing the results of the current study. Through a discussion, two researchers of this study decided on the items to be included in the table as research design, participants, year, location, data collection instruments, purposes, and findings. The researchers individually read, summarized, and coded each study with respect to the elements given in the table. The codes of the first and second researcher were validated through discussion and consensus was reached on Table 1, which helped to conduct the systematic review. Then, categorizing and synthesizing were used to analyze the findings in detail. As a first step, coding was conducted by means of repetitive reading of each document, and then categories were extracted to comprehend and elaborate each research study and its findings. After that categories were interpreted again according to commonalities and main themes were decided through discussion as benefits of pedagogical documentation, challenges, of pedagogical documentation, child participation (involvement of children in documentation practices), and strategies regarding the practice of pedagogical documentation. These categories were then explained by synthesizing the related research studies under the same umbrella to center upon and justify the related category. As a summary, research studies were synthesized with basing upon the previous categories in the findings part by integrating both thematic analysis and content analysis in this process.

\section{FINDINGS}

Detailed analysis of the current literature revealed that there are a limited number of empirical research studies specifically focusing on pedagogical documentation, and these have different research purposes and conclusions. Since the purpose of this study is to present a clear picture about the current literature on practices of pedagogical documentation, following sections present information related to that by categorizing and synthesizing the selected empirical studies' findings into subtitles of benefits, challenges, child participation, and strategies in implementation of pedagogical documentation. These subtitles were named with respect to the extracted commonalities in the reviewed research articles.

\section{Benefits of Pedagogical Documentation}

After implementing pedagogical documentation, various benefits of its practice were presented in the literature. Some of these benefits were listed as contributing to children's learning, teachers' awareness of learning processes, and parents' gaining a better understanding of their children's learning processes (Buldu, 2010). This supports that pedagogical documentation is providing a significant record of teaching and learning for each stakeholder (MacDonald, 2007) and making children's perspectives visible and open for reflection. To reach such benefits, children need to actively participate, and the teachers' response to the children's initiatives is also important for children to engage in this process according to Pettersson (2015). This was also mentioned by teachers as helping them to plan and develop pedagogical processes (Rintakorpi, 2016). In this 
regard, the active application of documentation to everyday practice in the kindergarten was related to careful and target-oriented planning and development (Rintakorpi \& Reunamo, 2017) since teachers practice documentation in different ways with respect to their purposes of documentation such as getting information and using as a tool for learning as exemplified by Alvestad and Sheridan (2015).

Within its nature, pedagogical documentation has a role of building a more participatory and equal early childhood education since the requirements of children with special needs must be taken into account, and democratic participation has to be provided equally among all children. This is important because in general, the interests of children with special needs are not considered compared to other children. Furthermore, children need to become a part of the daily routine in the classroom, and this also enables communication with the parents of the children. These indicate it's another benefit of providing equality in ECE settings as justified by Paananen and Lipponen (2016). Pedagogical documentation also connects with child-centered and carefully planned early childhood practices by taking into consideration to children's everyday activities as elaborated by Rintakorpi and Reunamo (2017). Moreover, it is evidenced in an experimental design that it enables children to be able to remember more factual information in documentation and worksheet (Fleck et al., 2013), and it promotes literacy by providing deeper understanding of children's interest, curiosity and strength while presenting literacy activities (Mac Donald, 2007). In particular, images have an important role in children's remembering, which points out the significance of documentation materials as suggested by Pettersson (2015).

Buldu, Şahin and Yllmaz (2018) investigated how pedagogical documentation contributes to development and learning of the children by conducting interviews with early childhood teachers. The main extracted themes from interviews are children's feeling of valued, responsibility taking, their expression of themselves, listening, and active involvement in learning process, learning motivation and interest, self-evaluation, and learning awareness. Early childhood teachers agreed that pedagogical documentation supports children's individual development positively as allowing them to take responsibility and feeling valued. It also improves their interpersonal skills and integrates them to learning process and assessment actively. In this regard, this study shows that pedagogical documentation contributes to interactive learning environment and democratic atmosphere in the classroom. As a result of the study, necessity of arranging environment and providing support for the teachers were also indicated. Similarly, Schulz (2015) also examined collected ethnographic data to look at documentation practices of teachers and concluded that documentation contributes to learning of children as becoming educational instruments.

In a study over 7 weeks' period, Aras and Tantekin Erden (2019) confirmed that documentation panels in pedagogical documentation process also contributes to children' self-regulatory and metacognitive abilities by means of sharing time sessions and reflective dialogues. In this way, children reflected on their thinking and learning in the naturalistic context of pedagogical documentation. Similarly, Liljestrand and Hammerberg (2017) focused on the competent and selfgoverned child in documentation process. Child was represented as competent in different respects clearly. By means of the documentation panel, this focus was reflected under three points: child as a good pal (accomplishing norms and values of social life), child as an autonomous investigator, and child as a public speaker. Recurring patterns were found in selected pieces of documentation $(n=20)$ to reach this finding.

In a research study of Paananen and Lipponen (2016), pedagogical documentation was specifically benefited as a tool for creating and maintaining the communication with parents for both teachers and children. They used various documentations including teacher observation diary, teacher self-documentations, ECE plans, and interviews with teachers to reach this finding. Rintakorpi, Lipponen and Reunamo (2014) also concluded in their case study in Finland that pedagogical documentation could be a tool in transition from home to kindergarten by making children's feelings and interests visible. The core underlying idea for their study is that children have 
their own views and experiences, and they have right to be heard. In line with this, Reynolds and Duff (2016) found that parents view pedagogical documentation as beneficial in improving communication between home and school since they feel a connection with child learning when teacher shares pedagogical documentation. This sharing process also contributes to children's positive self-identity according to them. Likewise, in the comprehensive study of Buldu (2010), teachers viewed pedagogical documentation as useful, giving one of the reasons as increasing communication with parents. The parents' perspectives also confirmed the teachers' responses related to pedagogical documentation in that it increased awareness and educated the parents, as well as increasing communication with their children.

On the other side, Sousa (2019) emphasized that there is a connection between educators' professional development and children's education and learning. Four pedagogical documentations were selected to reflect a teacher's professional development journey and then, interview was conducted with the teacher to learn about children's learning and teacher's professional development. It was found that documentation helps to make visible and revisit the learning situation of children for teachers. In this regard, it was concluded that documentation is empowering both children and teachers in connection to each other. Merewether (2018) also highlighted that there is an interconnection between children, adults, environment, strategies, and documentation as a whole and pedagogical documentation can be used to explore children's perceptions of outdoor spaces by enabling to listen them. Particularly, the role of pedagogical documentation for listening children was emphasized in this research.

Considering all of these findings, teachers' conceptions related to documentation were found to be positive, and the benefits of the practices were listed in the research study of Rintakorpi (2016) as professional development, making early childhood education and care visible, pedagogical processes, child centeredness and participation, communication with parents and children, and focusing on the children's views. In light of these, its positive correlation with child-centered methods were also pointed out in the conclusion of this research study. To sum up, pedagogical documentation is helpful for each stakeholder of the process by allowing children to revisit their ideas and develop their own thinking, by supporting teachers to plan, and by enabling parents to extend their children's study into home (Kang\& Walsh, 2018).

\section{Challenges of Pedagogical Documentation}

As well as having various benefits, different challenges were faced in the practice of pedagogical documentation. Some of the reported ones by teachers in different research studies are effort demanding, time consuming, lack of parent presence, lack of material equipment (Buldu, 2010), difficulties in learning about the documentation methods, insufficient technical equipment, and teachers' lack in technical skills (Rintakorpi, 2016). Kang and Walsh (2018) also analyzed and described challenges specifically for each step of documentation. These were mostly associated with time for recording and organizing, documenting children's own words, and preparing the displays. Many invisible aspects or workloads of documentation in preparation process was also mentioned by teachers. Moreover, since teachers tended to focus on children's enjoyment, the learning process is not reflected enough in the documentation. It was concluded that teachers need information about the process of documentation (Alvestad \& Sheridan, 2015). In line with this finding, lack of support related to training or education was also described as an obstacle by the teachers on usage of pedagogical documentation in the study of MacDonald (2007). Pedagogical documentation was introduced to teachers in five kindergarten classrooms in that study, and interviews were conducted in different periods with teachers and parents. The teachers were supported while they were using pedagogical documentation. The results of the study showed that after pedagogical documentation, the parents were better informed regarding the classroom routine. However, teachers identified the lack of support, finding time, and the parents' lack of presence as difficulties for the pedagogical documentation process. 
On the other side, in their study, Alvestad and Sheridan (2015) found that teachers document in various ways for different reasons but mostly they document information to report children's parents. Photo documentation was related with children's learning process, and this was mentioned as improving the learning process of children as enabling to make reflection on pedagogical processes. However, teachers mostly use documentation for planning purposes rather than learning related issues. Therefore, having various aims was described as another challenge of documentation. Specific problems were also reported between teachers' planning, documentation, and reflection (Alvestad \& Sheridan, 2015). For instance, in the study by Emilson and Samuelsson (2014), video observations of documentations in two different pre-schools were investigated with the focus being on communication between teacher and child. These video-recordings showed no communication or only teacher-directed communication. Also, the children's achievements were mostly documented, and the documented tasks were highly abstract, which was interpreted as giving importance to their accomplishments.

\section{Child Participation in Pedagogical Documentation}

In the studies that include children as active participants, the aim was to investigate the connection between pedagogical documentation and children's everyday activities (Rintakorpi \& Reunamo, 2017) and examine the communication between preschool teachers and the children in documentation situations (Emilson \& Samuelsson, 2014). It was found that educators generally prefer to use documentation in establishing connection with activity development and planning, and pedagogical documentation was correlated with small groups and differentiated education, and children's high level of involvement in the activity. The most probable reason for this is that when pedagogical documentation is used, the children tend to have freedom, and therefore rich documentation was related to the positive emotions of children, such as joy, surprise, and curiosity (Rintakorpi \& Reunamo, 2017).

Moreover, a significant correlation was found between the educators' type of interaction with children, such as safe and sensitive in pedagogical documentation (Rintakorpi \& Reunamo, 2017). In line with these studies that had a similar purpose, children's participation and preschool documentation were also presented in the research studies conducted by Pettersson $(2015 ; 2015 a)$, as well as a comprehensive investigation of pedagogical documentation in a study by Buldu (2010), which included children, families, and teachers. According to Pettersson (2015a), there are different forms of documentation, and child participation in this process is a complex issue as being described in three themes: participation as attendance, participation as involvement, and participation as influence. At this point, the children's interest and teachers' flexibility were found to facilitate the children's participation but this was also found to be restricted to certain areas including participation as attendance in which children are controlled by teachers, and participation as involvement referring to children's being engaged but not having any influence. The children were also found not to be active in the decision-making processes of the documentation topic or method (Pettersson, 2015a). The possible reason is that a relationship was found between planning and documentation, and the documentation focused on the teachers' planning, rather than on the children's learning processes (Alvestad \& Sheridan, 2015).

It was suggested that it is necessary for teachers to reflect on the kind of documentation that is necessary to obtain knowledge of the child's learning since documentation can become either an obstacle or opportunity for children and teachers in preschool as indicated by Alvestad and Sheridan (2015). In the study of Emilson and Samuelsson (2014), it was also found that preschool teachers become either silent observers or eager advocates of a particular discovery in this process. However, in both cases, communication is strategic and goal oriented. Likewise, Pettersson (2015) stated that the person who is documenting has a significant power in process, and documented material has an important role in memories of children. Therefore, according to Pettersson (2015), the child's voice is suppressed in the documentation process. To prevent the creation of an obstacle, Buldu (2010) 
suggested that pre-service teachers and in-service teachers should be supported in developing skills for pedagogical documentation.

In line with the previous findings, Bath (2012) also investigated children's participation in documentation and concluded that there is lack of children's involvement in recording their own progress and assessment. Especially written anecdotes exclude children from this process. Therefore, documentation was analyzed with some theoretical terms in this research article as deciding, decentralizing, disciplining, didactic, and dialogue. However, as a purpose of pedagogical documentation, adult and child communicative cooperation was emphasized, and it was suggested that both children and adults should be active in documentation through effective communication. Similarly, Knauf (2017) also investigated documentation practices and child participation in a comprehensive mixed method design as including staff, parents, and head of center as participants. Particularly, visual data was investigated in terms of child participation, and data was analyzed with reflective interpretation. It was found that portfolios, documentation panels, and presentation of children's works are the commonly used documentation practices. Child participation in these documentations is changing with respect to age, and older children are more able to participate in documentation because of their ability of using language for communication. However, in common sense, documentation was seen as educators' work and responsibility rather than reflection of children's experience. Child participation was conceptualized as only including works from children and few teachers pointed out to select pictures with children for documentation. Moreover, limited number of centers included child quotations in their documentation panels, and children's presentation of their own products were also less likely to be mentioned. Only a few centers as having an advanced documentation procedure managed to include children in documentation of their work.

As having a different data collection medium, Lindgren (2012) examined teachers' blog posts about pedagogical documentation as a part of an online course in which participant teachers attended. These blog posts were categorized into main themes in analysis. Teachers accepted pedagogical documentation as a positive method to see the child. Particularly, documentation course helped them to understand the core meaning of the pedagogical documentation. Although they viewed documentation as time consuming, they pointed out it to be manageable with organization in daily basis. However, teachers did not focus on children's voices in blog posts. Particularly, ethical concerns for children in pedagogical processes was new knowledge for these teachers. They astonished and frustrated about it. However, different ideas came up while discussing on this issue. For instance, overuse of the visual digital technology was the commonly agreed criticism. Overall, although preschool teachers accepted ethical concerns about taking children into account, positive sides of pedagogical documentation were dominant for them and they protected their rights of observing children in their views.

Despite some of the negative aspects, the available research revealed the benefits of pedagogical documentation, and how it contributes to understand children's perspectives, eases children's integration in becoming part of everyday life in preschool, and assists in examining equality in ECE as suggested by Paananen and Lipponen (2016). For instance, in the experimental study of Fleck et al. (2013), it was tested whether documentation can facilitate children's learning and episodic and semantic memory. Documentations or worksheets were used as reminders for children. Those children who were exposed to documentation or worksheet remembered more information than others who had not been reminded.

\section{Strategies for Implementation of Pedagogical Documentation}

Alnervik (2018) discussed systematic documentation for pedagogical documentation in Swedish context to contribute to knowledge about practice of pedagogical documentation. Research data was collected through jointly worked four preschools during 3 years' project period by field notes and interviews. Four steps were described to systemize the pedagogical documentation process, which are selecting tools for observation, having a structure for tools of pedagogical documentation, having 
an organization to visualize the documentation, and having an organization for conversations with colleagues about content of the pedagogical documentation. Particularly, choosing tools for observation and becoming organized in pedagogical documentation process are the crucial points which were strongly emphasized in this research paper.

Having a similar focus, Kang \& Walsh (2018) also investigated pedagogical documentation deeply in its practical context. Documentation process, teachers' interactions, and children's responses to documentations were the focused points of the study. To explore overall experiences with documentations, participant observations, meeting notes, and in-depth interviews were integrated into process. As a result, five stages were described for teachers' documentation as recording (photos, videos, and children's works), organizing, analyzing, creating displays, and reporting (parent-teacher conference, etc.). In other words, systematic documentation was conducted and suggested by teachers. Particularly photos and field notes were presented as helpful in articulating ideas clearly, and teacher mostly pointed out the making visible of children's learning with documentation. Practical suggestions for teachers and teacher educators were also provided in the study. For instance, recording less, organizing more, using a template. In line with these findings, Knauf (2019) investigated perspectives of teachers on documentation in a multicultural atmosphere of New Zealand and Germany with 24 early childhood teachers. The common aim of documentation for these teachers was to identify children's interests with the documentation. It was found that all teachers felt time pressure to complete documentation, and therefore they developed strategies to gain time in documentation process and deal with extra burdens caused by itself. These strategies are staff discussions, usage of multiple documentations, and setting priorities.

\section{DISCUSSION and CONCLUSIONS}

This is a comprehensive review paper synthesizing empirical research studies related to pedagogical documentation in early childhood education to answer the research question of "What do we know about practices of pedagogical documentation in early childhood education?" In this regard, this discussion part discusses the answer for this research question as well as interpreting the article features like sampling, research design, and location to explore whether there is a pattern in the current literature and get implications for the practice of pedagogical documentation.

In terms of sampling in the research studies, generally teachers were active participants and children were generally integrated in research studies (e.g., Emilson \& Samuelsson, 2014) without referring their views or examining their direct contribution to the process. Furthermore, it was stated in the research that children's participation was restricted to certain areas in documentation. The children were not active in deciding on documentation topic or method (Pettersson, 2015a) or recording their own progress (Bath, 2012) despite pedagogical documentation being mentioned as helping to internalize more child-centered pedagogy (Rintakorpi, 2016). However, pedagogical documentation in fact shows to teachers that child is curious, competent, and creative (Sousa, 2019). Especially, documentation panels show children's metacognitive and self-regulatory skills, and it improves the quality of discussion between teachers and children (Aras \& Tantekin Erden, 2019). For instance, in the study by Buldu (2010), some of the teachers advocated that pedagogical documentation contributes to children's participation, motivation, and interest in learning as providing opportunities for reflecting on their own learning. The most probable underlying reason is that pedagogical documentation might facilitate communication related to how children learn and help to focus on construction of knowledge (MacDonald, 2007). Moreover, pedagogical documentation is also a way of communication between each stakeholder of the process, including the children, teachers, and parents (Carr, 2001). On the other side, effective communication is also the way for providing children's active participation in documentation process (Bath, 2012). Therefore, it is a mutual process, and it might be beneficial to include children as active participants, as well as other participants and give importance to their voices in the process in order to improve 
the outcomes. In this regard, the view of teacher's dominancy in documentation should change to incomplete teacher view to eliminate power relations between teacher and child (Lindgren, 2012).

When the research designs were examined, only one study was planned as quantitative in nature (Rintakorpi \& Reunamo, 2017). Research on pedagogical documentation generally includes qualitative data, and therefore it is difficult to make generalization about the findings (Rintakorpi \& Reunamo, 2017). To provide this, valid and reliable data collection tools can be developed and used. Designing studies in different methodologies including quantitative, mixed method etc. might also increase the validity of the research findings.

Analysis of study locations confirmed that the research studies related to pedagogical documentation were limited to only a few countries. Conducted studies were mostly in European countries, which is most probably due to assessment being important in their curriculums. For instance, in Nordic countries, such as Finland, children's perspectives are rooted in the curricula (Paananen \& Lipponen, 2016). In the Swedish curriculum, children's participation in documentation is required (Pettersson, 2015). Similarly, in Norway, the relationship between documentation and preschool quality is emphasized (Alvestad \& Sheridan, 2015). However, research studies are still rare in those countries with taking into consideration to the priority in the curriculum (Rintakorpi, 2016). Due to the globalization of education, pedagogical documentation has also spread to North America, and various authors have undertaken research in Canada and the United States (Grieshaber \& Hatch, 2003; Cadwell, 2003; Kocher, 1999; Oken-Wright, 2001). However, since pedagogical documentation is based on collaborative processes in Reggio Emilia based classrooms, it is not expected that it will be easily adapted in kindergartens having a traditional classroom structure (MacDonald, 2007). Since empirical studies might present the current situation and provide implications for effective use of these tools, it seems to be an urgent necessity to create consciousness on the significance of this issue and encourage more research. Training and education for teachers might be effective for creating such changes (MacDonald, 2007) in countries having the traditional classroom structure.

Although various research studies made conclusions about the various benefits of pedagogical documentation, challenges were also reported mostly due to the need to save time and expend more extra effort. However, the benefits were more likely to be reported by teachers than challenges (Rintakorpi, 2016), and suggestions were offered to resolve the problems in the research studies. For instance, regarding time issue, it was suggested to integrate specific documentation activities into lesson plans (Kang \& Walsh, 2018). To overcome a problem related to parents' unwillingness, sharing was suggested by incorporating documentation panels into a school newsletter and sending those to the parents (Buldu, 2010). Despite the identified difficulties related to parents, pedagogical documentation was also described as a powerful tool by teachers to communicate with parents (Rintakorpi, 2016). In line with this, families viewed educators' sharing pedagogical documentation important in order to sense children's learning in a visible way (Reynolds \& Duff, 2016). However, it is important to keep in mind that the intention of documentation is not to showcase the performance of educators to parents, and the real focus should be on education (Knauf, 2017).

It was advocated that knowledge and skills are necessary for planning pedagogical documentation, and therefore pre-service and in-service teachers should be supported concerning this issue (Buldu, 2010) because it is considered that lack of support results in the teachers' inability to use pedagogical documentation (MacDonald, 2007). In line with this, Kang and Walsh (2018) recommended for teacher educators to integrate pre-service teachers in all aspects of documentations to make it authentic for them. It was also suggested that mentoring and support could be provided for pre-service teachers (Quinn \& Schwartz, 2011). Both pre-service and in-service teachers are suggested to get knowledge and skills about pedagogical documentation (Buldu, Sahin \& Yilmaz, 2018). Since documentation shows what happens in a preschool, this can become a way to visualize preschool teachers' part in and contribution to practice (Alnervik, 2018). If this underlying reason in usage of pedagogical documentation is rationalized for preschool teachers, it might be an encouraging factor for teachers to deal with difficulties in practice. On the other hand, knowledge and 
skills are not enough in this process, and it is also important to consider an organizational structure with considering time, technical equipment, etc. (Knauf, 2009).

In documentations, it was mostly the children's achievements (e.g., documenting what is done and what is taught in school) were visible. This was criticized as causing the risk of evaluating child through achievements, rather than their individual performance or who they are (Emilson \& Samuelsson, 2014). Thus, it was stated that teachers' responses to the children's initiatives are important to provide their participation in the process (Pettersson, 2015), and teacher commitment in pedagogical documentation process is necessary to get suggested benefits (Rintakorpi, 2016). In addition, the type of material was affective on children's participation in the documentation process as affecting their negotiations about narratives and meaning of labels (Pettersson, 2015) since image of child is shaped by used techniques and resources (Liljestrand \& Hammarberg, 2017). For instance, documentation and communication might guide children's remembering of facts, which was revealed in an experimental study by Fleck et al. (2013). Images were also found to affect children's memory, and sticky dots were also described as effective in identifying the importance of the documents (Pettersson, 2015).

It was interpreted that children's voices were made heard during the process of documentation, and teachers should critically analyze which documents are presented (Pettersson, 2015). Since there are different types of documentations, including limited documentation (creating obstacles for children and teachers), child-centered documentation (focusing on activities that children participate in), and learning-oriented documentation (focusing on what children learn), it is important for teachers to decide on the kind of documentation that reveals the children's learning and development in different content areas. (Alvestad \& Sheridan, 2015). To provide this, training related to pedagogical documentation can be beneficial for teachers (Rintakorpi \& Reunamo, 2017). Moreover, working as a group can decrease teachers' workload in the pedagogical documentation process and reveal the invisible part of the children's lives and experiences in school to parents. In this way, parents can see richness and diversity of children's learning experiences (Buldu, 2010). As a result, children can feel pride and well (Reynolds \& Duff, 2016), and pedagogical documentation can be helpful to create interconnection between children, adults, strategies, documentation and environment as a whole (Merewether, 2018). Overall, the teachers using pedagogical documentation were mostly satisfied with their professional practices. This documentation was related with children's safe attachment to educators (Rintakorpi \& Reunamo, 2017), and it enriched pedagogical environment for both teachers and children (Sousa, 2019).

Overall, this review of the literature leads us to conclude that pedagogical documentation has desired outcomes for children, parents, and teachers but this depends on the effectiveness of teachers' fulfilling their roles in the process. It is necessary for teachers to decide on what kind of documentation to implement to reflect on children's learning and development (Alvestad \& Sheridan, 2015). In order to explore this area in greater depth and support teachers regarding this issue, more empirical research studies concerning pedagogical documentation are needed. In particular, as indicated in the findings, it would be beneficial to plan research studies in different methodologies and make generalizations about it. For instance, action research might serve to explore solutions for overcoming identified challenges of pedagogical documentation. On the other side, designing research studies in quantitative nature might generate strong implications in terms generalizability, which is a gap in the literature right now.

To raise awareness of the need for this type of documentation, further studies might be conducted using similar instruments in various countries regarding different age groups and widening the range of participants in the research. Also, this issue might be investigated comprehensively by providing active participation of different stakeholders to process like families and children in order to be able to make heard different voices. Particularly, children's perspectives to themselves in documentation process might be worth to investigate (MacDonald, 2007). Investigation of children's own experiences through documentation would make documentation 
process more meaningful (Kang \& Walsh, 2018) as well as providing high-level of documentation processes. Therefore, research studies are required to explore the driving factors in sophisticated pedagogical documentation practices and enable children's participation in these documentation processes (Knauf, 2017). Furthermore, it might be better to increase the range of locations and interpret findings in cross-cultural atmosphere to get implications about its effective usage. This paper provides a picture about current situation of pedagogical documentation in the literature, which is a topic attracting growing attention day by day, and it needs to go forward in further studies.

\section{REFERENCES}

Alasuutari, M., Markström, A. \& Vallberg-Roth, A. (2014). Assessment and Documentation in Early Childhood Education. Abington: Routledge.

Alnervik, K. (2018). Systematic documentation: Structures and tools in a practice of communicative documentation. Contemporary Issues in Early Childhood, 19(1), 72-84.

Alvestad, T. \& Sheridan, S. (2015). Preschool teachers' perspectives on planning and documentation in preschool. Early Child Development and Care, 185(3), 377-392.

Aras, S. \& Tantekin Erden, F. (2019). Documentation panels: supporting young children's self-regulatory and metacognitive abilities. International Journal of Early Years Education, DOI:10.1080/09669760.2019.1592743.

Bath, C. (2012)."'I can't read it; I don't know": young children's participation in the pedagogical documentation of English early childhood education and care settings. International Journal of Early Years Education, 20(2), 190-201.

Black, P., \& Wiliam, D. (1998). Inside the black box: raising standards through classroom assessment. Phi Delta Kappan, 80(2), 139-148.

Blum, R.E. \& Arter, J.A. (1996). Setting the stage. In R.E.Blum \& J.A. Arter (Eds.), A handbook for student performance assessment in an era of restructuring (pp.1:1-1:2). Alexandria, VA: Association for Supervision and Curriculum Development.

Boehm, A., \& Weinberg, R. (1997). The classroom observer: Developing observation skills in early childhood settings (3rd Ed.). New York: Teachers College Press.

Bowen, G.A. (2009). Document Analysis as a Qualitative Research Method. Qualitative Research Journal, 9(2), 27-40.

Buldu, M. (2010). Making learning visible in kindergarten classrooms: Pedagogical documentation as a formative assessment technique. Teaching and Teacher Education, 26, 1439-1449.

Buldu, M, Şahin, F. \& Yllmaz, A. (2018). Exploring the Contribution of Pedagogical Documentation to the Development and Learning of Young Children from Teacher Perspective. Elementary Education Online, 17(3), 1444-1462.

Cadwell, L. B. (2003). Bringing learning to life: The Reggio approach to early childhood education. New York: Teachers College Press.

Carr, M. (2001). Assessment in early childhood settings: Learning stories. London: Paul Chapman.

Caldwell, L. B. (1997). Bringing Reggio Emilia home. An innovative approach to early childhood education. New York: Teachers College Press.

Chen, S.S. \& Cheng, Y. (2011). Implementing curriculum-based learning portfolio: A case study in Taiwan. Early Child Development and Care, 181 (2), 149-164.

Dahlberg, G., Moss, P. \& Pence, A.R. (2007). Beyond Quality in Early Childhood Education and Care. Languages of Evaluation (2nd Ed.). London: Routledge.

Downs, A., \& Strand, P.S. (2006). Using assessment to improve the effectiveness of early childhood education. Journal of Child \& Family Studies, 15 (6), 671-680.

Edwards, C. P., Gandini, L., \& Forman, G. (1998). The hundred languages of children: The Reggio Emilia approach to early childhood education. Norwood, NJ: Ablex Publishing.

Emilson, A. \& Samuelsson, I.P. (2014). Documentation and communication in Swedish Preschools. Early Years, $34(2), 175-187$.

Epstein, A.S., Schweinhard, L., DeBruin-Parechi, J. \& Robin, K.B. (2004). Preschool Assessment: A Guide to Developing a Balanced Approach. Preschool Policy Facts. Brunswick, NJ: National Institute for Early Education Research. 
Fleck, B.K.B., Leichtman, M.D., Pillemer, D.B. \& Shanteler, L. (2013). The effects of documentation on young children's memory. Early Childhood Research Quarterly, 28, 568- 577.

Fleet A., Honig, T., Robertson, J., Semann, A., Stepherd, W. (2011). What's Pedagogy Anyway? Using pedagogical documentation to engage with the Early Years Learning Framework, New South Wales, and Australia: Children's Services Central.

Goldhaber, J., \& Smith, D. (1997). You look at things differently: The role of documentation in the professional development of a campus childcare center staff. Early Childhood Education Journal, 25(1), 3-10.

Grieshaber, S., \& Hatch, A. J. (2003). Pedagogical documentation as an effect of globalization. Journal of Curriculum Theorizing, 19(1), 89-103.

Kagan, S. L. (2003). Children's readiness for school: Issues in assessment. International Journal of Early Childhood, 35, 114-120.

Kang, J. \& Walsh, D. (2018). Documentation as an integral part of teaching: early childhood teachers' systematic search for good teaching. Journal of Early Childhood Teacher Education, 39(4), 262-277.

Katz, L.G. \& Chard, S.C. (1996). The Contribution of Documentation to the Quality of Early Childhood Education, ERIC Database 0/PS/96/2.

Kingore, B. (2008). Developing portfolios for authentic assessment, PreK-3: Guiding potential in young learners. Thousand Oaks, CA: Corwin Press.

Kinney, L. \& Wharton, P. (2008). An Encounter with Reggio Emilia: Children's Early Learning Made Visible. Abington: Routledge.

Klenowski, V. (2002). Developing Portfolios for Learning and Assessment. London: Routledge Falmer.

Kline, L.S. (2008). Documentation panel: The "Making learning visible" project. Journal of Early Childhood Teacher Education, 29, 70-80.

Knauf, H. (2017). Documentation as a tool for participation in German early childhood education and care. European Early Childhood Education Research Journal, 25(1), 19-35.

Knauf, H. (2019). Documentation Strategies: Pedagogical Documentation from the Perspective of Early Childhood Teachers in New Zealand and Germany. Early Childhood Education Journal, 48, 11-19.

Kocher, L. (1999). The rabbit habitat-documenting a kindergarten project. Canadian Children, 24(2), 15-22.

Liljestrand, J. \& Hammarberg, A. (2017). The social construction of the competent, self-governed child in documentation: Panels in the Swedish preschool. Contemporary Issues in Early Childhood, 18(1) 39-54.

Lindgren, A. (2012). Ethical Issues in Pedagogical Documentation: Representations of Children through Digital Technology. International Journal of Early Childhood, 44, 27-340.

Löfgren, H. (2017). Learning in preschool: Teachers' talk about their work with documentation in Swedish preschools. Journal of Early Childhood Research, 15(2), 130-143.

MacDonald, M. (2007). Toward formative assessment: The use of pedagogical documentation in early elementary classrooms. Early Childhood Research Quarterly, 22, 232-242.

McAfee, O., \& Leong, D. J. (2011). Assessing and guiding young children's learning and development (5th Ed.). Upper Saddle River, NJ: Pearson.

McAfee, A., Leong, D.J., \& Bodrova, E. (2004). Basics of Assessment. A primer for early childhood education. Washington, DC: National Association for the Education of Young Children.

Merewether, J. (2018). Listening to young children outdoors with pedagogical documentation. International Journal of Early Years Education, 26 (3), 259-277.

Morrison, G. S. (2013). Fundamentals of early childhood education (7th Ed.). Upper Saddle River, NJ: Pearson.

Oken-Wright, P. (2001). Documentation: Both mirror and light. Innovations in Early Education: The International Reggio Exchange, 8(2), 5-15.

Oliveira-Formosinho, J. \& Formosinho, J. (2012). Pedagogy-in-Participation: Childhood Association Educational Perspective. Porto: Porto Editora.

Paananen, M. \& Lipponen, L. (2016). Pedagogical documentation as a lens for examining equality in early childhood education. Early Child Development and Care, DOI: 10.1080/03004430.2016.1241777.

Pettersson, K. E. (2015). Sticky Dots and Lion Adventures Playing a Part in Preschool Documentation Practices. International Journal of Early Childhood, 47, 443-460.

Pettersson, K.E. (2015a). Children's participation in preschool documentation practices. Childhood, 22 (2), pp231-247.

Quinn, S.M.F. \& Schwartz, K. (2011). Preservice teachers' perceptions of pedagogic documentation techniques in early childhood teacher preparation. Journal of Early Childhood Teacher Education, 32, 39-54. 
Reynolds, B. \& Duff, K. (2016). Families' perceptions of early childhood educators' fostering conversations and connections by sharing children's learning through pedagogical documentation. Education 3-13, 44(1), 93-100.

Rinaldi, C. (2000). Subjectivity and Intersubjectivity in Children's Learning. Presentation at the NAEYC Conference, Atlanta, GA, USA.

Rintakorpi, K. (2016). Documenting with early childhood education teachers: pedagogical documentation as a tool for developing early childhood pedagogy and practices. Early Years, 36(4), 399-412.

Rintakorpi, K., Lipponen, L. \& Reunamo, J. (2014). Documenting with parents and toddlers: A Finnish case study. Early Years, 34(2), 188-197.

Rintakorpi, K., \& Reunamo, J. (2017). Pedagogical documentation and its relation to everyday activities in early years. Early Child Development and Care, 1-12.

Rous, B., Lobianco, T., Moffett, C. L., \& Lund, I. (2005). Building preschool accountability systems: Guidelines resulting from a national study. Journal of Early Intervention, 28, 50-64.

Sancisi, L. \& Edgington, M. (2015). Developing High Quality Observation, Assessment and Planning in the Early Years: Made to Measure. Abington: Routledge.

Schulz, M. (2015). The Documentation of children's learning in early childhood education. Children \& Society, 29, 209-218.

Sousa, J. (2019). Pedagogical documentation: the search for children's voice and agency. European Early Childhood Education Research Journal, 27(3), 371-384.

Tarr, P. (2010). Curiosity, curriculum, and collaboration entwined: Reflections on pedagogical documentation. Canadian Children, 35(2), 10-14.

Tarr, P. (2011). Reflections and shadows: Ethical issues in pedagogical documentation. Canadian Children, 36(2), 11-16.

Thornton, L. \& Brunton, P. (2009). Understanding the Reggio Approach: Early Years Education in Practice. (2 ${ }^{\text {nd }}$ Ed.). Abington: Routledge.

Wien, C.A., Guyevskey, V., \& Berdoussis, N. (2011). Learning to document in Reggio-inspired education. Early Childhood Research \& Practice, 13(2), 1-12.

Wortham, S. C. (2012). Assessment in early childhood education (6th Ed.). Upper Saddle River, NJ: Pearson. Wortham, S.C. \& Hardin, B.J. (2016). Assessment in Early Childhood Education (7 $7^{\text {th }}$ Ed.). USA: Pearson. 


\section{APPENDIX}

Table 1. Study characteristics

\begin{tabular}{|c|c|c|c|c|c|c|}
\hline Reference & Purpose & Design & Participants & Measures & Location & Findings \\
\hline $\begin{array}{l}\text { Alnervik } \\
\text { (2018) }\end{array}$ & $\begin{array}{l}\text { Provide information } \\
\text { about structures and } \\
\text { tools related to different } \\
\text { aspects of pedagogical } \\
\text { documentation. }\end{array}$ & Qualitative & Teachers & $\begin{array}{l}\text { Field notes and } \\
\text { interviews }\end{array}$ & Sweden & $\begin{array}{l}\text { Pedagogical documentation is a } \\
\text { systematic work. Usage of various } \\
\text { tools and organization are important } \\
\text { in documentation process. }\end{array}$ \\
\hline $\begin{array}{l}\text { Alvestad \& } \\
\text { Sheridan } \\
\text { (2015) }\end{array}$ & $\begin{array}{l}\text { Investigate challenges, } \\
\text { problems, and dilemmas } \\
\text { related to planning and } \\
\text { documentation. }\end{array}$ & Qualitative & Teachers & Interview & Norway & $\begin{array}{l}\text { There is a relationship between } \\
\text { planning and documentation, and } \\
\text { documentation improves teachers' } \\
\text { understanding of pedagogical work } \\
\text { with children. Flexible planning is } \\
\text { based on children's interests, and } \\
\text { previous experiences are } \\
\text { emphasized. }\end{array}$ \\
\hline $\begin{array}{c}\text { Aras \& } \\
\text { Tantekin } \\
\text { Erden (2019) }\end{array}$ & $\begin{array}{l}\text { Look for evidence on } \\
\text { how pedagogical } \\
\text { documentation } \\
\text { contributes to children's } \\
\text { self-regulatory and } \\
\text { meta-cognitive abilities. }\end{array}$ & Qualitative & Children & $\begin{array}{l}\text { Participant } \\
\text { observation and } \\
\text { interview }\end{array}$ & Turkey & $\begin{array}{l}\text { Documentation panels contribute to } \\
\text { children's self-regulatory and meta- } \\
\text { cognitive abilities by means of } \\
\text { sharing time and reflective } \\
\text { dialogues. Peer interaction is an } \\
\text { important factor in this process. }\end{array}$ \\
\hline Bath (2012) & $\begin{array}{l}\text { Examine children's } \\
\text { participation in } \\
\text { pedagogical } \\
\text { documentation. }\end{array}$ & Qualitative & Children & $\begin{array}{l}\text { Participatory } \\
\text { methods to get } \\
\text { children's } \\
\text { comments like } \\
\text { photos, games } \\
\text { etc. }\end{array}$ & England & $\begin{array}{l}\text { There is lack of child involvement in } \\
\text { documentation process, and adult- } \\
\text { child communication is effective in } \\
\text { providing this. Documentation was } \\
\text { analyzed as deciding, decentralizing, } \\
\text { disciplining, didactic and dialogue. }\end{array}$ \\
\hline
\end{tabular}


Table 1. Continued

\begin{tabular}{|c|c|c|c|c|c|c|}
\hline Reference & Purpose & Design & Participants & Measures & Location & Findings \\
\hline Buldu (2010) & $\begin{array}{l}\text { Examine pedagogical } \\
\text { documentation with } \\
\text { children, families, and } \\
\text { teachers. }\end{array}$ & Qualitative & $\begin{array}{l}\text { Children, } \\
\text { parents, and } \\
\text { teachers }\end{array}$ & $\begin{array}{l}\text { Observation, } \\
\text { interview, and } \\
\text { questionnaire }\end{array}$ & $\begin{array}{l}\text { United } \\
\text { Arab } \\
\text { Emirates }\end{array}$ & $\begin{array}{l}\text { Pedagogical documentation } \\
\text { contributes to children's learning, } \\
\text { teachers' awareness of learning } \\
\text { processes, and parents' gaining a } \\
\text { better understanding of learning } \\
\text { processes in their children's } \\
\text { education. }\end{array}$ \\
\hline $\begin{array}{c}\text { Buldu, Şahin } \\
\text { \& Ylmaz } \\
\text { (2018) }\end{array}$ & $\begin{array}{l}\text { Explore the contribution } \\
\text { of pedagogical } \\
\text { documentation on } \\
\text { children's learning and } \\
\text { development as a } \\
\text { teaching, learning and } \\
\text { assessment method. }\end{array}$ & Qualitative & Teachers & Interview & Turkey & $\begin{array}{l}\text { Pedagogical documentation has a } \\
\text { variety of contributions for children } \\
\text { including feeling valued, taking } \\
\text { responsibility, expressing own self, } \\
\text { listening, active participation in } \\
\text { learning process, motivation to learn, } \\
\text { self-evaluation and learning } \\
\text { awareness. }\end{array}$ \\
\hline $\begin{array}{c}\text { Emilson \& } \\
\text { Samuelsson } \\
(2014)\end{array}$ & $\begin{array}{l}\text { Investigate } \\
\text { communication between } \\
\text { preschool teachers and } \\
\text { children in } \\
\text { documentation } \\
\text { situations. }\end{array}$ & Qualitative & $\begin{array}{l}\text { Children and } \\
\text { teachers }\end{array}$ & $\begin{array}{c}\text { Video } \\
\text { observations }\end{array}$ & Sweden & $\begin{array}{l}\text { Preschool teachers become either } \\
\text { silent observers or eager advocates of } \\
\text { a particular discovery. Mostly, } \\
\text { children's achievements are the focus } \\
\text { of the documentation. }\end{array}$ \\
\hline $\begin{array}{l}\text { Fleck et al. } \\
\text { (2013) }\end{array}$ & $\begin{array}{l}\text { Test whether } \\
\text { documentation } \\
\text { facilitates children's } \\
\text { learning and episodic } \\
\text { and semantic memory. }\end{array}$ & Experimental & $\begin{array}{l}\text { Preschool } \\
\text { children }\end{array}$ & Interview & England & $\begin{array}{l}\text { Children in documentation and } \\
\text { worksheet conditions remembered } \\
\text { more factual information than others } \\
\text { who have not been reminded. }\end{array}$ \\
\hline
\end{tabular}


Table 1. Continued

\begin{tabular}{|c|c|c|c|c|c|c|}
\hline Reference & Purpose & Design & Participants & Measures & Location & Findings \\
\hline $\begin{array}{c}\text { Kang \& Walsh } \\
\text { (2018) }\end{array}$ & $\begin{array}{l}\text { Examine documentation } \\
\text { process and challenges } \\
\text { of teachers. }\end{array}$ & Qualitative & Teachers & $\begin{array}{l}\text { Participant } \\
\text { observation, } \\
\text { interview, } \\
\text { meeting notes }\end{array}$ & US & $\begin{array}{l}\text { Five stages to follow documentation } \\
\text { were described for teachers a } \\
\text { recording, organizing, analyzing, } \\
\text { creating displays and reporting, Time } \\
\text { to record while teaching and getting } \\
\text { children's exact words are some of } \\
\text { the identified challenges. }\end{array}$ \\
\hline Knauf (2017) & $\begin{array}{l}\text { Investigate } \\
\text { documentation } \\
\text { practices and child } \\
\text { participation in these } \\
\text { documentations. }\end{array}$ & $\begin{array}{l}\text { Mixed } \\
\text { methods }\end{array}$ & $\begin{array}{l}\text { Early } \\
\text { childhood } \\
\text { centers }\end{array}$ & $\begin{array}{l}\text { Forms, surveys, } \\
\text { interviews, } \\
\text { photos }\end{array}$ & Germany & $\begin{array}{l}\text { Portfolios, documentation panels and } \\
\text { presentation of children's works are } \\
\text { the common documentation } \\
\text { practices. Children are less likely to } \\
\text { involve in documentation of their } \\
\text { daily work. }\end{array}$ \\
\hline Knauf (2019) & $\begin{array}{l}\text { Explore the strategies } \\
\text { teachers integrate } \\
\text { documentation into } \\
\text { daily schedule }\end{array}$ & Qualitative & Teachers & Interviews & $\begin{array}{l}\text { Germany } \\
\text { and New } \\
\text { Zealand }\end{array}$ & $\begin{array}{l}\text { Teachers develop strategies to gain } \\
\text { time and deal with difficulties in } \\
\text { documentation process. }\end{array}$ \\
\hline $\begin{array}{l}\text { Liljestrand \& } \\
\text { Hammarberg } \\
\quad(2017)\end{array}$ & $\begin{array}{l}\text { Explore how } \\
\text { documentation panel } \\
\text { constructs competent } \\
\text { and self-governed child. }\end{array}$ & Qualitative & Preschools & $\begin{array}{l}\text { Documentations } \\
\text { of children, } \\
\text { written texts by } \\
\text { teachers, photos }\end{array}$ & Sweden & $\begin{array}{l}\text { Children are self-competent in } \\
\text { different respects. Three images are } \\
\text { described including: the child as a } \\
\text { good pal, autonomous investigator, } \\
\text { and public speaker. }\end{array}$ \\
\hline $\begin{array}{l}\text { Lindgren } \\
\text { (2012) }\end{array}$ & $\begin{array}{l}\text { Explore children's role in } \\
\text { pedagogical } \\
\text { documentation. }\end{array}$ & Qualitative & Teachers & Blog posts & Sweden & $\begin{array}{l}\text { Children's participation in } \\
\text { documentation is generally restricted } \\
\text { to become a subject being looked at. }\end{array}$ \\
\hline
\end{tabular}


Table 1. Continued

\begin{tabular}{|c|c|c|c|c|c|c|}
\hline Reference & Purpose & Design & Participants & Measures & Location & Findings \\
\hline $\begin{array}{l}\text { MacDonald } \\
(2007)\end{array}$ & $\begin{array}{l}\text { Examine potential of } \\
\text { pedagogical } \\
\text { documentation as a } \\
\text { formative assessment in } \\
\text { literacy instruction and } \\
\text { communicating learning } \\
\text { to children and their } \\
\text { families. }\end{array}$ & Qualitative & $\begin{array}{l}\text { Parents and } \\
\text { teachers }\end{array}$ & $\begin{array}{l}\text { Interview and } \\
\text { observation }\end{array}$ & Canada & $\begin{array}{l}\text { Pedagogical documentation helps } \\
\text { teachers and parents to understand } \\
\text { children's strengths and provides } \\
\text { significant records of teaching. }\end{array}$ \\
\hline $\begin{array}{l}\text { Merewether } \\
\text { (2018) }\end{array}$ & $\begin{array}{l}\text { Investigate usage of } \\
\text { documentation to listen } \\
\text { children. }\end{array}$ & Qualitative & Children & $\begin{array}{l}\text { Observation, } \\
\text { conversation, } \\
\text { photos, field } \\
\text { notes. }\end{array}$ & Australia & $\begin{array}{l}\text { In connection to pedagogical } \\
\text { documentation, children, adults and } \\
\text { nonhuman elements all work } \\
\text { together. Pedagogical documentation } \\
\text { is a way to listen children in } \\
\text { pedagogical situations. }\end{array}$ \\
\hline $\begin{array}{l}\text { Paananen \& } \\
\text { Lipponen } \\
\text { (2016) }\end{array}$ & $\begin{array}{l}\text { Investigate how } \\
\text { pedagogical } \\
\text { documentation } \\
\text { contributes to } \\
\text { understanding } \\
\text { children's perspectives, } \\
\text { eases children's } \\
\text { perspectives to become } \\
\text { part of their everyday } \\
\text { lives and helps to } \\
\text { examine equality in ECE } \\
\text { settings. }\end{array}$ & $\begin{array}{l}\text { Multi- } \\
\text { method }\end{array}$ & $\begin{array}{l}\text { Teachers and } \\
\text { children }\end{array}$ & $\begin{array}{l}\text { Observation, } \\
\text { documentation, } \\
\text { interview, and } \\
\text { individual } \\
\text { ECE plans }\end{array}$ & Finland & $\begin{array}{l}\text { Pedagogical documentation makes } \\
\text { children's perspectives visible and } \\
\text { open for reflection and contributes to } \\
\text { equality in ECE settings. }\end{array}$ \\
\hline
\end{tabular}


Table 1. Continued

\begin{tabular}{|c|c|c|c|c|c|c|}
\hline Reference & Purpose & Design & Participants & Measures & Location & Findings \\
\hline $\begin{array}{c}\text { Pettersson } \\
\text { (2015a) }\end{array}$ & $\begin{array}{l}\text { Present types of } \\
\text { children's participation } \\
\text { in preschool } \\
\text { documentation. }\end{array}$ & Qualitative & $\begin{array}{l}\text { Children and } \\
\text { teachers }\end{array}$ & Observation & Sweden & $\begin{array}{l}\text { Children's participation in } \\
\text { documentation was reported in three } \\
\text { themes: participation as } \\
\text { attendance, participation as } \\
\text { involvement, and participation as } \\
\text { influence. }\end{array}$ \\
\hline $\begin{array}{l}\text { Pettersson } \\
(2015)\end{array}$ & $\begin{array}{l}\text { Review pedagogical } \\
\text { documentation and } \\
\text { evaluative } \\
\text { documentation. }\end{array}$ & Qualitative & $\begin{array}{l}\text { Children and } \\
\text { teachers }\end{array}$ & Observation & Sweden & $\begin{array}{l}\text { Evaluation of individual children is } \\
\text { not consistent with Sweden } \\
\text { curriculum. Photographs projected } \\
\text { on the walls enact negotiations from } \\
\text { the memory of the conducted activity. } \\
\text { Particularly, images have an } \\
\text { important role in children's } \\
\text { remembering. }\end{array}$ \\
\hline $\begin{array}{l}\text { Reynolds \& } \\
\text { Duff (2016) }\end{array}$ & $\begin{array}{l}\text { Explore families' beliefs, } \\
\text { perceptions and } \\
\text { experiences of } \\
\text { pedagogical } \\
\text { documentation while } \\
\text { educators are sharing } \\
\text { their children's learning } \\
\text { experiences. }\end{array}$ & Qualitative & Families & Questionnaire & Australia & $\begin{array}{l}\text { Sharing pedagogical documentation } \\
\text { with families improves } \\
\text { communication between home and } \\
\text { school, and children gain pride and } \\
\text { positive identity. }\end{array}$ \\
\hline $\begin{array}{l}\text { Rintakorpi, } \\
\text { Lipponen \& } \\
\text { Reunamo, } \\
\text { (2014) }\end{array}$ & $\begin{array}{l}\text { Explore how } \\
\text { pedagogical } \\
\text { documentation can help } \\
\text { to understand a child. }\end{array}$ & Qualitative & Families & Observation & Finland & $\begin{array}{l}\text { Pedagogical documentation provides } \\
\text { communication between home and } \\
\text { kindergarten and makes children's } \\
\text { interests and feelings visible. }\end{array}$ \\
\hline
\end{tabular}




\section{Table 1. Continued}

\begin{tabular}{|c|c|c|c|c|c|c|}
\hline Reference & Purpose & Design & Participants & Measures & Location & Findings \\
\hline $\begin{array}{c}\text { Rintakorpi } \\
\text { (2016) }\end{array}$ & $\begin{array}{l}\text { Examine experienced } \\
\text { benefits and challenges } \\
\text { of documentation by } \\
\text { teachers. }\end{array}$ & Qualitative & $\begin{array}{c}\text { Kindergarten } \\
\text { teachers }\end{array}$ & Questionnaire & Finland & $\begin{array}{l}\text { Teachers' conceptions related to } \\
\text { documentation are positive including } \\
\text { professional development, making } \\
\text { early childhood education visible, } \\
\text { child centeredness, communication } \\
\text { with parent, etc. However, challenges } \\
\text { are also reported. }\end{array}$ \\
\hline $\begin{array}{l}\text { Rintakorpi \& } \\
\text { Reunamo } \\
\text { (2017) }\end{array}$ & $\begin{array}{l}\text { Examine connection } \\
\text { between pedagogical } \\
\text { documentation and } \\
\text { children's everyday } \\
\text { activities. }\end{array}$ & Quantitative & $\begin{array}{l}\text { Children and } \\
\text { ECE } \\
\text { educators }\end{array}$ & $\begin{array}{l}\text { Quantitative } \\
\text { scales and } \\
\text { observation }\end{array}$ & Finland & $\begin{array}{l}\text { Documentation in kindergarten is } \\
\text { related to child centeredness, well- } \\
\text { being, and ability to learn. }\end{array}$ \\
\hline Schulz (2015) & $\begin{array}{l}\text { Investigate } \\
\text { documentation } \\
\text { practices of teachers } \\
\text { and explore how these } \\
\text { practices contribute to } \\
\text { children's learning }\end{array}$ & Qualitative & $\begin{array}{l}\text { Kindergarten } \\
\text { groups }\end{array}$ & $\begin{array}{c}\text { Observation } \\
\text { and field notes }\end{array}$ & Germany & $\begin{array}{l}\text { Documentation practices contribute } \\
\text { to children's learning by creating a } \\
\text { culture for them. Documents record } \\
\text { learning process and they are created } \\
\text { for the child. Therefore, they are } \\
\text { educational instruments focusing on } \\
\text { children's learning. }\end{array}$ \\
\hline Sousa (2019) & $\begin{array}{l}\text { Investigate and develop } \\
\text { children's learning in } \\
\text { connection with } \\
\text { educators' professional } \\
\text { development. }\end{array}$ & Qualitative & Teacher & $\begin{array}{c}\text { Four } \\
\text { pedagogical } \\
\text { documentations } \\
\text { and an } \\
\text { interview }\end{array}$ & - & $\begin{array}{l}\text { Pedagogical documentation provides } \\
\text { connection between teachers } \\
\text { professional development and } \\
\text { children's learning. It empowers both. }\end{array}$ \\
\hline
\end{tabular}

